\title{
30. On Regulatory Power, Compliance, and the Role of the Court of Justice in EU Environmental Law $^{1}$ Marjan Peeters and Mariolina Eliantonio
}

\section{INTRODUCTION}

This book has aimed to draw insights into the use of different regulatory instruments in the field of EU environmental law and the role of the Court of Justice of the European Union (CJEU) in putting them into practice. The individual chapters have each delved into a specific theme of this wide and dynamic field of law. In turn, this concluding chapter will provide overarching observations related to how the EU has used its regulatory power to steer towards environmentally friendly behaviour (section 2), will delve into the deep concerns related to the compliance with and enforcement of EU environmental law, thereby also highlighting the important role of civil society (section 3 ), and will characterize how the CJEU has contributed to the effective implementation of EU environmental legislation (section 4). Section 5 concludes with an outlook on EU environmental law scholarship.

\section{THE USE OF REGULATORY POWER TO PROTECT THE ENVIRONMENT}

\subsection{Complexity of Regulatory Structures and the Challenge of Understanding EU Environmental Law}

The EU has succeeded in building a vast regulatory framework aiming at the protection of the environment. The main question as regards the EU competence in environmental matters is not whether the EU can legislate or not, but rather how the EU can - and should - legislate. ${ }^{2}$ This 'how' question can be approached from several angles. One issue stands out: the complexity of the regulatory approaches. While EU environmental law has a broad scope covering many environmental values, the regulation of one single environmental issue often results in a complex set of rules. Such complexity is for instance clearly evident in the chapters on light-vehicle emissions, energy efficiency, and land use and land use change. ${ }^{3}$ Regarding specifically vehicle emissions, 'a flurry of legislative directives as

1 This chapter is built upon the chapters of this book; we will refer to the authors of the chapters when using their findings.

2 As observed by Helle Tegner Anker.

3 Respectively the chapters by Nicolas de Sadeleer, Thomas Schomerus and Seita Romppanen. 
well as legislative and non-legislative regulations that are to a great extent entangled' can be observed. ${ }^{4}$ Such intricate regulatory frameworks concerning pressing environmental problems provide challenges for those who need to apply them. For instance, road transport - being only one domain covered by EU environmental law - contributes to about one-fifth of the EU's total emissions of specifically $\mathrm{CO}_{2}$, and is one of the major, and even deadly, sources of air pollution in the EU. ${ }^{5}$ Undertaking a comprehensive analysis of the adequacy of all rules relevant for the transport sector - not only vehicle emissions, but also shipping and aviation emissions - is utterly demanding.

Moreover, in specific fields, environmental legislation has been frequently amended, leading to important changes in the regulatory approaches. In the case of the EU emissions trading instrument, changes were necessary to improve the functioning of the instrument. ${ }^{6}$ Moreover, changes to EU environmental legislation are often induced by international environmental law developments. In fact, the EU can be seen as a global actor trying to promote environmental protection at the international level. ${ }^{7}$ This endeavour can be explained given the vested interest of the EU in ensuring over time its relevance in international environmental governance, not only with the purpose of improving the condition of the planet, but perhaps also in order to 'globally uphold specific cultural values, rooted in liberal democracy and free-market economy' ${ }^{8}$ The topic of climate change is illustrative of the need to improve existing EU legislation: given the increased acknowledgment of the seriousness of the problem and the need to take action, codified in Article 2 of the Paris Agreement, the EU has changed and partly strengthened various pieces of legislation after the adoption of the Paris Agreement in 2015. ${ }^{9}$

In addition to the many changes in environmental legislation, particularly in view of strengthening the approach to environmental protection, the challenge of understanding the regulatory approach is caused by vague legislative terms that, on a case-by-case basis, are filled in by decisions of the CJEU. As a consequence, a thorough study of the relevant case law concerning a specific regulatory framework or specific legal provision is needed in order to be able to get a comprehensive picture of the direction and meaning of the regulatory approach taken by the EU legislator. The chapters on nature conservation, waste, access to information, and environmental impact assessment are illustrative examples of this phenomenon. ${ }^{10}$ In addition, given the difficult structure of EU environmental legislation, the CJEU may be called upon to clarify the applicability of overlapping or contrasting provisions. For instance, the European Commission has recognized that many complex questions exist at the interface between chemicals law, product law, and waste

\footnotetext{
4 Quoted from Nicolas de Sadeleer.

5 European Environment Agency, Greenhouse gas emissions from transport (published 22.11.2018), available at <https://www.eea.europa.eu/data-and-maps/indicators/transport-emis sions-of-greenhouse-gases/transport-emissions-of-greenhouse-gases-11>. See about the health risks caused by air pollution Kendro Pedrosa and Bernard Vanheusden.

6 Stefan Weishaar.

7 See Article 191 TFEU.

8 As stated by Antonio Cardesa-Salzmann and Elisa Morgera.

9 See particularly also the chapter by Estelle Brosset and Sandrine Maljean-Dubois.

10 Chapters by An Cliquet, Chris Backes, Uzuazo Etemire and Agustín García-Ureta, respectively. In the chapter on waste, it is explained that the CJEU decided on the relationship between two different directives both of which were applicable to waste.
} 
law. From a democratic perspective, it is to be hoped for that optimal solutions can be found at the legislative level instead of 'transferring' this task to the CJEU. ${ }^{11}$

The challenge to understand the applicable legislation can also rest with one single definition, as can be illustrated with the definition of waste, which at first sight seems simple: 'waste means any substance or object which the holder discards or intends or is required to discard'. ${ }^{12}$ The case law of the CJEU illustrates that the uncertainty hidden in this definition has caused many issues in practice. In fact, a certain amount of 'judicial law-making' can be observed, in the sense that the CJEU has developed criteria through which practice can identify whether something should be called 'waste'; and, interestingly, in several instances the case law is subsequently consolidated in legislation. ${ }^{13}$ As will be further discussed in section 4, also the chapters on nature conservation, environmental impact assessment and the EU Emission Trading System (ETS) show that the Court has been frequently addressed to clarify the applicable rules. ${ }^{14}$

The difficulties that practice experiences with unclear definitions or provisions in the legislation should not be underestimated, not only in view of the lack of acceptance that may emerge at the Member States level, and perhaps among EU citizens in general, but also in view of possible uncertainties with regard to the taking of (criminal) enforcement actions. $^{15}$

\subsection{A Wide Range of Regulatory Approaches in Tackling Environmental Challenges}

EU environmental legislation employs a wide variation of regulatory approaches to deal with environmental problems, with different forms of authorizations of specific activities (such as in the case of nature conservation vis-à-vis GMO authorization), ${ }^{16}$ different ways to regulate goods (such as chemical substances vis-à-vis emissions by vehicles) ${ }^{17}$ and different ways to regulate the overall environmental quality (such as water and air quality). ${ }^{18}$ Even with respect to the same topic, one can see differences in the regulatory

11 Chris Backes, referring to the EU Commission, Communication on the implementation of the circular economy package: options to address the interface between chemical, product and waste legislation, COM 2018/032/final.

12 Chris Backes, discussing Article 3(1) of the Waste Framework Directive. But see for instance also Gyula Bándi pointing at the lack of consistency in the way in which the principle of external integration is regulated in the TFEU and the Charter.

${ }_{13}$ As aptly explained by Chris Backes; he also explains the practice of the European Commission to incorporate in its guidance documents case law from the CJEU.

14 Chapters by An Cliquet, Agustín García-Ureta and Stefan Weishaar, respectively.

15 In this vein, also the immense regulatory complexity of the energy efficiency legislation could contribute to short-falling implementation of the EU legislation at Member States level; see furthermore the chapter by Thomas Schomerus. See about the advantages of criminal law provisions regarding the concrete endangerment of the environment the chapter from Michael Faure. In this vein, he criticizes the absence of autonomous, independent crimes in the Environmental Criminal Liability Directive, whereby criminal law could be applied even in the absence of a violation of administrative obligations.

16 Chapters from An Cliquet and Giulia Claudia Leonelli, respectively.

17 Chapters from Martin Führ and Julian Schenten, and Nicolas de Sadeleer, respectively.

18 Chapters from Nathalie Hervé-Fournerau, and Kendro Pedrosa and Bernard Vanheusden, respectively. 
approach: in the case of the regulation of genetically modified organisms, the risk assessment is regulated differently under the 2001 ('Deliberate Release') Directive ${ }^{19}$ and 2003 ('GM Food and Feed') Regulation. ${ }^{20}$ Remarkable in the regulatory approach is the fact that national measures taken on the basis of EU law often have effect beyond the national territory of the issuing authority. ${ }^{21}$

While the diversity of regulatory approaches may be advantageous for the purposes of providing a fine-tuned regulation for a specific problem, the potential for streamlining and simplification could be further considered. For instance, it could be examined whether it would be possible and desirable to merge the environmental assessment procedure of the Habitats Directive ${ }^{22}$ with those contained in the Environmental Impact Assessment ${ }^{23}$ and Strategic Environmental Assessment Directives. ${ }^{24}$ Along the same lines, there have been a number of 'fitness checks' of environmental legislation, and some have led to the withdrawal of a number of proposals for environmental legislation, such as the proposed Soil Framework Directive ${ }^{25}$ and the implementation of the access to justice pillar of the Aarhus Convention. ${ }^{26}$ However, streamlining environmental regulatory approaches and simplification in EU environmental law could imply that specificities are lost and that consequently the mainstream approach would be less fit for purpose.

Clearly, several environmental law measures intend to introduce a level playing field for the European industry. Both the Industrial Emissions Directive (IED) ${ }^{27}$ and the Environmental Liability Directive ${ }^{28}$ are examples of this effort. However, with respect to the latter issue, harmonizing the different liability regimes existing in Member States, with very heterogeneous criteria to establish liability for environmental damage, has proven to

19 Directive 2001/18/EC of the European Parliament and of the Council of 12 March 2001 on the deliberate release into the environment of genetically modified organisms [2001] OJ L-106/1.

20 Regulation (EC) No 1829/2003 of the European Parliament and of the Council of 22 September 2003 on genetically modified food and feed [2003] OJ L-268/1. See on this topic the chapter by Giulia Claudia Leonelli.

21 Several examples of transnational measures in the field of environmental law are discussed by Luca De Lucia and Maria Chiara Romano.

22 Council Directive 92/43/EEC of 21 May 1992 on the conservation of natural habitats and of wild fauna and flora [1992] OJ L-206/7.

23 Directive 2011/92/EU of the European Parliament and of the Council of 13 December 2011 on the assessment of the effects of certain public and private projects on the environment [2012] OJ L-26/1.

24 Directive 2001/42/EC of the European Parliament and of the Council of 27 June 2001 on the assessment of the effects of certain plans and programmes on the environment [2001] OJ L-197/30. Agustín García-Ureta observed that the EU has not attempted to engage in this merging process.

25 Proposal for a Directive of the European Parliament and of the Council establishing a framework for the protection of soil and amending Directive 2004/35/EC, COM/2006/0232 final.

26 Proposal for a Directive of the European Parliament and of the Council on access to justice in environmental matters, COM/2003/0624 final. These initiatives are discussed by Helle Tegner Anker.

27 Directive 2010/75/EU of the European Parliament and of the Council of 24 November 2010 on industrial emissions (integrated pollution prevention and control) [2010] OJ L-334/17.

28 Directive 2003/87/EC of the European Parliament and of the Council of 13 October 2003 establishing a scheme for greenhouse gas emission allowance trading within the Community and amending Council Directive 96/61/EC [2003] OJ L-275/32. 
be long and difficult. ${ }^{29}$ The adopted Environmental Liability Directive hence contains a number of general and vague provisions, and, in this respect, in the implementation process different national approaches have prevailed, not least because of the language and terminological differences which are almost inevitable in a multi-lingual context such as the EU one. ${ }^{30}$ In that sense, the level playing field has only been put into practice to a limited extent.

One of the striking examples of the difference in regulatory approaches in EU environmental legislation is the economic type of regulation in the field of greenhouse gases, and the command and control type of regulation in the framework of authorizations to carry out industrial activities. ${ }^{31}$ The EU-wide cap on the greenhouse gas emissions, established by the EU Emissions Trading Directive, ${ }^{32}$ provides a legal guarantee for emissions reduction, and thereby a clear and effective environmental measure if compliance is sufficiently ensured. This single-focused regulatory approach - only dealing with a couple of (as such very damaging) greenhouse gases - stands in contrast with one of the basic aims of the regulation of industrial emissions, which is to adopt an integrated approach for the permitting of industrial activities in order to protect the environment as a whole by dealing with many different pollutants affecting different environmental media, such as, inter alia, air and water. The difference between the two regulatory instruments also rests in the room for decision-making that is left to the polluters: while the EU Emission Trading System leaves in principle a large margin of freedom for industries to decide on what reduction approaches to adopt, particularly in view of the price to be paid when causing emissions, a command and control permit leaves less freedom for the industries. However, for a good understanding of how the regulation plays out for the industries, further analysis is needed, since compliance with emission limit values may still enable some room for decision-making for the industry on, for instance, what technology to install. Furthermore, the Industrial Emissions Directive is entrenched with flexibilities that can be used for deciding on the precise content of an individual permit, which seems to be embedded in an integrative approach in order to weigh the different aspects of the specific activity for which a permit is requested and the relevant (also local) environmental conditions in view of the protection of the environment as a whole.

While both the EU Emissions Trading System and the Industrial Emissions Directive lead to 'hard' legal obligations for industries, with, on the one hand, the obligation to surrender sufficient greenhouse gas allowances in order to compensate for the greenhouse emissions in a certain year and, on the other hand, the obligation to comply with the emission limit values in an industrial emissions permit, other regulatory approaches provide for softer forms of governance, both for Member States and the polluting actors. First of all, the 2018 Energy Union and Climate Action Regulation ${ }^{33}$ provides a governance

\footnotetext{
29 Chapter by Barbara Pozzo.

30 Also noted by Barbara Pozzo.

31 See respectively the chapters from Stefan Weishaar (on the EU Emissions Trading Directive), and Lolke Braaksma and Hanna Tolsma (on the Industrial Emissions Directive).

32 Directive 2004/35/CE of the European Parliament and of the Council of 21 April 2004 on environmental liability with regard to the prevention and remedying of environmental damage OJ L-143/56.

33 Regulation (EU) 2018/1999 of the European Parliament and of the Council of 11 December 2018 on the Governance of the Energy Union and Climate Action [2018] OJ L-328/1.
} 
regime with no hard substantive targets but procedural requirements, most importantly regarding the development of national climate and energy plans. ${ }^{34}$ This approach is thus 'hard' in its procedural commitments, and 'soft' - or flexible - in its content. ${ }^{35}$ Other legislative provisions that only encourage Member States to take action and hence can be qualified as soft governance, are provided in the Waste Framework Directive ${ }^{36}$ and the Energy Efficiency Directive. ${ }^{37}$ The latter, for example, does not contain binding energy efficiency targets for Member States, and the 'the freedom of Member States to set their national contributions based either on primary or final energy consumption or primary or final energy savings, or on energy intensity, should continue not to be restricted' ${ }^{38}$

Soft approaches can also be identified with regard to companies. For instance, the obligation to disclose information on non-financial values is a rather soft obligation: it is hard in its procedural commitment, but does not have binding consequences for the performance of companies. ${ }^{39} \mathrm{~A}$ focus on self-responsibility of actors can clearly be identified also in the regulation of chemicals, commonly referred to as REACH. ${ }^{40}$ This Regulation is based on the principle that it is for actors (manufacturers, importers and downstream users) to ensure that they manufacture, place on the market or use such substances that do not adversely affect human health or the environment. Basically, the control of substancerelated risks is clearly assigned to the industrial actors, who have to demonstrate that for each stage of the life cycle of the substance the risks are adequately controlled. Whether this regulatory approach is trustworthy may be questioned, and the 'high share of deficient dossiers puts the entire approach of industry self-responsibility into question' ${ }^{41}$

While soft approaches leave room for different solutions, adapted to the specific circumstances of the Member States, also harder law approaches enable Member States to develop policies that fit to the national circumstances, such as is the case with the Effort Sharing Regulation, ${ }^{42}$ that puts binding greenhouse gas emission limits on Member States,

34 Estelle Brosset and Sandrine Maljean-Dubois. See also for monitoring and reporting obligations in view of the 'Circular Economy Package' Chris Backes, referring to Article 9 of the Waste Framework Directive.

35 Estelle Brosset and Sandrine Maljean-Dubois.

36 Directive 2008/98/EC of the European Parliament and of the Council of 19 November 2008 on waste and repealing certain Directives [2008] OJ L-312/3. As observed by Chris Backes when discussing Articles 8 and $8 \mathrm{a}$ of the Waste Framework Directive.

37 Directive 2012/27/EU of the European Parliament and of the Council of 25 October 2012 on energy efficiency, amending Directives 2009/125/EC and 2010/30/EU and repealing Directives 2004/8/EC and 2006/32/EC [2012] OJ L-315/1.

38 As quoted by Thomas Schomerus (recital 6 of the 2018 Energy Efficiency Directive).

39 As very critically discussed by Beate Sjåfjell and Andrew Johnston.

40 Regulation No 1907/2006 of the European Parliament and of the Council of 18 December 2006 concerning the Registration, Evaluation, Authorisation and Restriction of Chemicals $(\mathrm{REACH})$, establishing a European Chemicals Agency, amending Directive 1999/45/EC and repealing Council Regulation (EEC) No 793/93 and Commission Regulation (EC) No 1488/94 as well as Council Directive 76/769/EEC and Commission Directives 91/155/EEC, 93/67/EEC, 93/105/EC and 2000/21/EC [2006] OJ L-396/1. Discussed by Martin Führ and Julian Schenten.

41 According to Martin Führ and Julian Schenten.

42 Regulation (EU) 2018/842 of the European Parliament and of the Council of 30 May 2018 on binding annual greenhouse gas emission reductions by Member States from 2021 to 2030 contributing to climate action to meet commitments under the Paris Agreement and amending Regulation (EU) No 525/2013 [2018] OJ L-156/26. 
but leaves to Member States the freedom to develop policies on how to achieve them. Also in the field of water policy, diversity is needed, given the variety of environmental conditions in the Member States that have to be taken into account when regulating the water status. As stated by the Water Framework Directive, '[P]riority should be given to action within the responsibility of Member States through the drawing up of programmes of measures adjusted to regional and local conditions', and, consequently, a certain margin of flexibility is granted to Member States. ${ }^{43}$

Furthermore, diversity can also emerge in case Member States engage in adopting more stringent environmental policy measures. This possibility for further action is enshrined in Article 193 TFEU, although Member States face limits for going the extra mile. ${ }^{44}$ Moreover, in product-related legislation such as on GMOs, in some cases Member States are allowed to shield their territory from the transnational effects generated by EU legislation, such as in the case of seeds containing GMOs. ${ }^{45}$

In sum, on the one hand, there are good reasons for following a multifaceted regulatory approach allowing Member States and polluters to consider optimal solutions given the specific domestic circumstances, and even to apply stricter standards than required by EU environmental legislation. However, on the other hand, the diversity of approaches entails that more efforts have to be undertaken to understand and to apply the regulatory package, and also to measure how the diverse regulatory approaches play out in view of achieving the envisaged environmental aims. Moreover, it is uncertain whether soft governance forms will result in meaningful environmental protection.

\subsection{Gradual Improvements - and Recommendations for More Secure Ones}

Overall, given the analysis provided in many of the chapters, one can notice that the body of EU environmental legislation shows a process of gradual improvement. For example, the EIA Directive has been amended a number of times, for the purposes of, amongst others, aligning the directive with the public participation requirements stemming from the Aarhus Convention or strengthening the approach by widening the scope of the instrument. ${ }^{46}$ Also the energy efficiency legislation shows a process of incremental changes in the legislation, thereby introducing innovative concepts such as 'the Japanese top-runner' approach. ${ }^{47}$ Furthermore, as of January 2020, REACH will provide obligations specifically designed for nanomaterials, although it is yet uncertain as to what this change will entail for existing substances and nanoforms thereof. ${ }^{48}$ This

43 Preamble para 13 of Directive $2000 / 60 /$ EC of the European Parliament and of the Council of 23 October 2000 establishing a framework for Community action in the field of water policy [2000] OJ L-327/1; see on this flexibility, the chapter by Nathalie Hervé-Fournerau.

44 Leonie Reins.

45 Luca De Lucia and Maria Chiara Romano discuss several examples where EU legislation allows individual Member States to unilaterally protect the environment without needing to discuss this decision (in a subsequent phase) with either the other national authorities or those of the EU.

46 Agustín García-Ureta.

47 Thomas Schomerus, who uses the example of innovation from his chapter, i.e. the Japanese standard.

48 Martin Führ and Julian Schenten. 
latter development is an example of the legislative approach being amended to include new technological developments, albeit rather late.

Also with regard to the EU Emissions Trading System, changes have been applied to improve the environmental effectiveness: a new mechanism (the Market Stability Reserve Mechanism) was introduced in 2018 in order to establish more scarcity related to the available amount of emission allowances. This approach was unthinkable at the time of the adoption of the Directive that established the EU Emissions Trading System. This example illustrates that it seems almost impossible to have a perfect regulatory approach from the beginning, and, by learning and doing, improvements can be brought to the relevant regulatory instruments. That the lessons can be hard may be dramatically illustrated by the car emissions case, which clearly showed flaws of the relevant EU scheme, and where rules for type approval were not clear enough and not homogenously applied in the Member States. ${ }^{49}$ However, the enacted legislative reform still does not seem to be the best option possible, since it still relies on a decentralized application by national 'type approval' authorities. ${ }^{50}$ This is unfortunately generally in line with the - in this book fiercely criticized - decentralized approach towards inspection and enforcement in the EU. 51

In view of this learning by doing, legal and other scholarship can indeed play a role in commenting upon weaknesses of existing legislation and pointing at possible improvements, as is for instance the case concerning obligatory disclosure of non-financial information for companies, which is possibly too soft to counteract the structural problem that short-term interests of shareholders often prevail. ${ }^{52}$ Possibilities for improvement are also identified with respect to the access to information legislation. Although the EU legislation already provides for a robust framework for the public to exercise the right of access to environmental information, the potential for strengthening this right is nevertheless identified, particularly with regard to the Aarhus Regulation ${ }^{53}$ that applies to EU institutions. ${ }^{54}$ In this vein, more attention to informational provisions in the energy efficiency legislation is also advocated for, particularly in the sense of actively informing the public. ${ }^{55}$ Also in the field of air quality legislation, which as such can be qualified as a comprehensive legislative framework, the environmental ambition

49 Nicolas de Sadeleer.

50 As argued by Nicolas de Sadeleer.

51 See about the cumbersome process regarding the attempts to develop a more co-ordinated approach regarding the supervision of national environmental inspection systems the chapter by Hedemann-Robinson, and the plea for granting enforcement powers to the European Environment Agency or a similar agency in the chapter by Michael Faure. See about the development of the European Environment Agency and the deliberation of its (limited) mandate: Annalisa Volpato and Ellen Vos. In section 3, we will proceed with the discussion of strengthening (also by harmonizing and centralizing) the inspection powers in EU environmental law.

52 As argued by Beate Sjåfjell and Andrew Johnston.

53 Regulation (EC) No 1367/2006 of the European Parliament and of the Council of 6 September 2006 on the application of the provisions of the Aarhus Convention on Access to Information, Public Participation in Decision-making and Access to Justice in Environmental Matters to Community institutions and bodies [2006] OJ L-264/13.

54 Uzuazo Etemire.

55 Thomas Schomerus, arguing that much more should be done to inform the general public and communicate the importance of energy efficiency and energy saving. 
could be improved, particularly in view of the recommendations of the World Health Organisation. ${ }^{56}$

Furthermore, factual data - such as data on air pollution - illustrate the need for improvement of (the implementation of) the applicable legislation. In the case of transport, the reductions in air emissions per car are undermined by traffic increase, and, moreover, air pollution problems are also caused by other sources than transport. The European Environmental Agency is tasked with providing information on the state of affairs of the environment to the EU institutions, thereby particularly assisting the Commission with scientific and technical expertise, although many of its information collection activities are also disseminated to the wider public. ${ }^{57}$ Nonetheless, the car emission example shows how the setting of ambitious environmental targets is frequently hindered by political considerations and bargaining. ${ }^{58}$

In sum, the body of EU legislation changes over time, and there are many examples of legislative amendments aimed at improving the regulatory approach, although these 'improvements' by means of new legal provisions may raise new questions. At the same time, there is still room for improvement of environmental legislation in several domains. Moreover, the legislative practice of the EU provides examples of measures aimed at reducing the environmental ambition, which was the case with ending the applicability of the EU Emissions Trading System for extraterritorial flights, even though the CJEU had found none of the legal concerns that were put forward in a challenge to the expansion valid. ${ }^{59}$ Finally, it is interesting to note that, by introducing highly ambitious environmental approaches, certain environmental legislation may become redundant, such as could be the case with waste law. ${ }^{60}$ And, indeed, if the EU manages to steer towards a carbon neutral society, the complex EU ETS may cease to exist somewhere in the course of this century. . .!

\section{COMPLIANCE AND ENFORCEMENT, INCLUDING ACTION BY CIVIL SOCIETY}

\subsection{The Implementation Deficit and the Efforts to Improve Compliance}

Separate scrutiny is needed of the issue of compliance and enforcement, and particularly, the 'implementation deficit' that is so manifest in EU environmental law. ${ }^{61}$ Painfully illustrative is the example of the 2010 Energy Performance of Buildings Directive: ${ }^{62}$ the

\footnotetext{
56 Kendro Pedrosa and Bernard Vanheusden.

57 Annalisa Volpato and Ellen Vos.

58 Nicolas de Sadeleer.

59 Case C-366/10, Air Transport Association of America and others $v$ Secretary of State for Energy and Climate Change ECLI:EU:C:2011:864. This topic is shortly discussed by Stefan Weishaar.

60 Chris Backes.

61 Michael Faure, discussing the opportunities and limits of criminal law in this respect. Martin Hedemann- Robinson points at the fact that EU environmental legislation is estimated to represent some $80 \%$ of Member States' environmental legislation, which illustrates that the implementation deficit is a gigantic problem.

62 Directive 2010/31/EU of the European Parliament and of the Council of 19 May 2010 on the energy performance of buildings OJ L-153/13.
} 
deadline set for transposition was not met by any Member State. ${ }^{63}$ The widespread poor implementation of the EU's environmental acquis threatens the credibility of the Union's development of a common policy for a high level of protection of the environment. ${ }^{64}$ One may even wonder whether in practice a race to the bottom is taking place between Member States with regard to the poor implementation of EU environmental law. ${ }^{65}$ Indeed, several reports and studies have underlined a longstanding and widespread state of poor implementation and application of EU environmental law at national level (in fields such as waste, nature and biodiversity, air quality, noise as well as water quality and management). ${ }^{66}$ Furthermore, the environmental sector has often been at the top of the European Commission's infringement activities undertaken under Articles 258 and 260 TFEU against Member States failing to adhere to their obligations under EU environmental law. ${ }^{67}$

The question that can be raised is whether there is any light on the horizon with respect to what has now become an endemic problem in the context of EU environmental law. The answer to this question emerging from the different contributions is a rather mixed one. The CJEU has certainly played an important role in this respect, such as by paving the way for strengthening the compliance toolkit by allowing the EU legislator to prescribe Member States to establish criminal sanctions in case of non-compliance with EU environmental legislation. ${ }^{68}$ This contrasts very much with the fact that there is hardly any harmonization in EU environmental legislation of administrative sanctions that have to be applied by Member States, so that often only the general principle applies that national enforcement measures must be effective, proportionate and dissuasive. ${ }^{69}$ This is also true for how to carry out inspections and monitoring, although various specific pieces of environmental legislation, such as the Industrial Emissions Directive, contain rules on monitoring and inspections. ${ }^{70}$ This 'sectoral track' approach to inspection regulation in the EU environmental policy sector exemplifies, on the one hand, the pragmatic stance that is being taken, and, on the other hand, its fragmentation, which may make the environmental acquis in turn less comprehensible. ${ }^{71}$

At the same time, clear barriers exist in the EU for establishing a more meaningful package of enforcement approaches, including the establishment, ultimately, of an

\footnotetext{
63 As discussed by Thomas Schomerus.

64 As discussed by Martin Hedemann-Robinson.

65 Michael Faure refers to the possibility for Member States to hide behind the formal implementation of European environmental legislation without providing any information on how this legislation is enforced in practice.

66 Martin Hedemann-Robinson provides a number of studied undertaken to come to these conclusions.

67 Martin Hedemann-Robinson and Melanie Smith.

68 Michael Faure - but see the concluding section in which he points at the gigantic problem of lack of information with regard to inspection and enforcement activities by Member States.

69 Case C-68/88, Commission v Greece ECLI:EU:C:1989:339.

70 Lolke Braaksma and Hanna Tolsma. Martin Hedemann-Robinson comprehensively provides other examples.

71 Martin Hedemann-Robinson has used this 'sectoral track' expression, and explains it by providing examples of different approaches.
} 
'Environmental Protection Agency' which would have powers to check compliance in the Member States. ${ }^{72}$ This was as such the original plan when the European Environmental Agency (EEA) was set up, and the proposal to grant it not only decision-making powers, but also extensive inspection and supervisory powers, did receive the support of the European Parliament. However, this proposal, opposed by the Commission, afraid to have a competitor in environmental policy-making, was not followed, as is shown by the limited powers with which the EEA is currently endowed. ${ }^{73}$ Also for assessing the conformity of cars with applicable emission regulations, the establishment of a one single authority in charge of supervising the system instead of 28 national authorities is proposed as an improvement. ${ }^{74}$

The barrier for strengthening the inspection provisions in EU environmental law has a fundamental cause: the introduction and subsequent strengthening of the subsidiarity principle ${ }^{75}$ facilitates political opinions to keep national governments in decisive positions regarding the organization and application of inspection tasks. A harmonization (in binding law) of minimum criteria for environmental inspections in the Member States - now only contained in a Recommendation - will hence probably stay theory, although favoured widely in environmental scholarship. ${ }^{76}$ At the same time, it is also recognized that a further harmonization of, for example, inspection provisions could lead to more 'symbolic legislation without clear effects on improving environmental quality'. ${ }^{77}$ A more optimistic view comes from the possibility that the use of procedural environmental rights, such as access to environmental information, and the possibility for members of the public to address non-compliance with national environmental law provisions, may be effective in the battle against the compliance deficit. ${ }^{78}$

Since it is impossible for authorities to control all activities of polluting entities, self-monitoring is part of several EU environmental legislative approaches, such as with car transport emissions: manufacturers are called on to prove that all new vehicles sold, registered or put into service comply with these new emission standards, for which a certificate of conformity is essential. ${ }^{79}$

Furthermore, it should be pointed out that the involvement of 'third parties' in monitoring activities can be increasingly detected as a regulatory tool to ensure compliance with EU environmental law. One striking example is that of the use of verifiers in the EU Emissions Trading System. While it has the advantage that monitoring costs need to be borne by the polluters themselves, this choice comes as such with a risk. For instance, the independence of the verifiers checking the conformity of cars with emission standards

\footnotetext{
72 As mentioned by Michael Faure.

73 Annalisa Volpato and Ellen Vos.

74 Nicolas de Sadeleer.

75 Together with the current Article 197(2) TFEU which prevents harmonization of administrative capacity for implementing Union law.

76 See respectively Martin Hedemann-Robinson and Michael Faure.

77 Michael Faure (discussing harmonization of criminal sanctions).

78 See Uzuazo Etemire with respect to the important of access to environmental information as a tool to foster environmental democracy and Ludwig Krämer on the doctrine of direct effect, which allows individuals to rely on national (environmental) law before the national courts.

79 Nicolas de Sadeleer.
} 
can be questioned in view of the income they get from car manufacturers when executing this task. ${ }^{80}$

Of course, next to these decentralized tools to ensure compliance, the infringement proceedings still remain as the main centralized instrument that the Commission, as the guardian of the Treaties, can and does use to ensure compliance with EU environmental law. Environmental policy has long been high on the Commission's political infringement agenda. ${ }^{81}$

According to the Commission's 2017 data on infringements, environmental policy accounted for the largest proportion of launched and open proceedings, as well as the largest number of second round infringement cases under Article 260(2) TFEU. ${ }^{82}$ However, '[T]he infringement mechanism is not the main enforcement tool of any sector; rather it is, in government speak, for steering, not rowing. ${ }^{83}$ Indeed, the Commission has developed a set of tools and techniques to render the infringement process as the mechanism of last resort. Nevertheless, in light of the specific features of environmental law, the Commission still spends a considerable amount of energy enforcing the implementation of environmental law through the use of the infringement mechanism and the financial sanction. ${ }^{84}$ In this context, specific mention must be made of the possibility for the Commission to issue interim measures in the framework of infringement proceedings: this tool is indeed particularly important for environmental enforcement, given the potential of this mechanism to prevent environmental damage from occurring. ${ }^{85}$ If (serious) noncompliance by Member States with environmental obligations occurs, it is to be hoped that this remedy will be used by the Commission and the Court in order to provide an effective protection to the environment.

\subsection{The Role of Civil Society and the Enforcement of EU Environmental Law}

Next to inspections by authorities, self-monitoring, and monitoring by third parties, civil society can also play an important role in the enforcement of the EU environmental acquis. ${ }^{86}$ Indeed, the environmental policy sector accounts for the second largest number of complaints from the public concerning non-compliance in the context of infringement proceedings. ${ }^{87}$

However, apart from bringing complaints to the Commission, civil society is relegated to a rather marginal role in the context of the centralized enforcement of EU environmental law. ${ }^{88}$ Matters are, however, different with respect to the decentralized enforcement mechanisms. A powerful tool in this respect has been the doctrine of

\footnotetext{
80 Nicolas de Sadeleer.

81 Melanie Smith.

82 Hedemann-Robinson.

83 Melanie Smith.

84 Melanie Smith.

85 Melanie Smith.

86 See on the importance of ENGOs not only Matthijs van Wolferen and Mariolina Eliantonio, but also the chapters by Ludwig Krämer and Nathalie Hervé-Fournereau.

87 As noted by Martin Hedemann-Robinson and Melanie Smith.

88 Melanie Smith.
} 
direct effect. Created by the Court of Justice as an instrument to empower individuals to bring violations of EU law to the attention of national courts, and thus to complement the centralized enforcement activity carried out by the Commission through the infringement proceedings, the role of direct effect in environmental law has not always been fully straightforward. Indeed, in the orthodox understanding of the notion, one of the conditions for direct effect is that the provision in question confers rights on individuals. This limitation would make the doctrine of direct effect largely useless in the field of environmental law, as many provisions, such as those contained in the Habitats Directive, are not as such meant to confer rights on anyone. However, in the more recent case law of the CJEU, the concept that a provision of EU law must confer rights on individuals has been abandoned, in the sense that a provision which contains an obligation for Member States and which is unconditional and sufficiently precise gives individuals the right to rely on such a provision before national courts (and national administrations). ${ }^{89}$ While this is certainly a welcome development in terms of empowerment of individuals and civil society to censor violations of EU environmental law, it also raises questions as to the relationship between direct effect and consistent interpretation. While this relationship is not fully settled in the case law of the Court of Justice, there are indications that, in the Court's understanding, the possibility of the use of the doctrine of consistent interpretation should always be tested, before relying on direct effect. If this path is followed by the Court of Justice, one might wonder what the future of direct effect is. One very likely consequence is that the priority given to consistent interpretation will make the doctrine of direct effect largely superfluous. ${ }^{90}$

As is well known, individuals and ENGOs can only plead violations of EU environmental law before national courts if they gain access to those very courts. In this context the Aarhus Convention and its access to justice provisions, together with the case law of the Court of Justice has been pivotal to enlarge access to court for ENGOs, especially in legal systems with restrictive standing rules, such as Germany. ${ }^{91}$ At the same time, it is regrettable that the Court of Justice is not applying the same high standards to the standing rules applicable at the EU level, and, thereby, has significantly hindered the access of ENGOs before the Luxembourg courts. ${ }^{92}$

\subsection{Civil Society and its Role for Strengthening the Ambition of Environmental Decision-making}

Enforcement of legal obligations would largely be meaningless if they were not sufficiently ambitious to ensure an adequate environmental protection. Therefore, participation by citizens and particularly ENGOs in the decision-making concerning such obligations is of utmost importance, not least to ensure that the decisions by national authorities comply with the requirements and boundaries set by EU law. ${ }^{93}$ Some EU legal instruments give

A9 noted by Ludwig Krämer.

90 Ludwig Krämer.

91 As noted by Matthijs van Wolferen and Mariolina Eliantonio.

92 Matthijs van Wolferen and Mariolina Eliantonio.

93 See on public participation, Lorenzo Squintani and Goda Perlaviciute. 
ample opportunity for such participation. ${ }^{94}$ However, carrying out such public participation procedures is surrounded with difficulties, and the highly technical and scientific dimension that often characterizes environmental issues may entail that it is hard for authorities to convince the public about the soundness of the outcome of the decisionmaking process. ${ }^{95}$ Also, despite the obligation to ensure participatory rights as provided by the Aarhus Convention and implemented in EU law, participation in environmental decision-making still displays a number of lacunae. One point of concern is that a sufficiently early engagement of ENGOs does not seem to be guaranteed. ${ }^{96}$ In view of this, it could be wondered to which extent the right to public participation in environmental decision-making is not largely a paper tiger. More empirical research as to how public participation has played a role in environmental decision-making is in this respect needed. ${ }^{97}$ Also the example of GMOs, and the opposition that marketing of GMOs has often received from citizens and media, provides a striking example of civil society engagement, especially in light of the Commission's stance that GMO risks must be run as long as the adverse effects of GMOs have not been scientifically established. In this light, it has been argued that it is time to 're-democratise and re-legitimise EU governance of GMOs ... beyond "sound" science and economic cost-benefit analysis'. ${ }^{98}$

The 'twin tool' to public participation is access to environmental information, which is instrumental to enable informed participation in environmental decision-making, and effective access to justice in environmental matters. However, also in this area, the efforts of the EU to comply with the access to information provisions contained in the Aarhus Convention has not been fully successful. ${ }^{99}$

Next to further attention as to how public participation rights can help to achieve more ambitious environmental decision-making, other innovative avenues have to be explored. In light of this, a specific category of third parties could contribute to strengthening the decision-making, namely, the competitors on the market, such as in the chemicals market. Here, particularly 'companies which might benefit from a limited or even refused authorisation' with regard to the chemicals regulation, and who may promote certain innovations that are more environmentally friendly, may play an important role in strengthening the environmental ambition of the decision-making. ${ }^{100}$ More particularly, the European Chemicals Agency could more actively enhance contribution to the decision-making from such third parties. ${ }^{101}$

94 See the example from the Water Framework Directive, discussed by Nathalie HervéFournereau and that of the Environmental Impact Assessment Directive, discussed by Agustín García-Ureta.

95 Nathalie Hervé-Fournereau.

96 Lorenzo Squintani and Goda Perlaviciute.

97 Lorenzo Squintani and Goda Perlaviciute.

98 As discussed at length in the chapter by Giulia Claudia Leonelli.

99 As concluded by Uzuazo Etemire.

100 Martin Führ and Julian Schenten.

101 Martin Führ and Julian Schenten. Also interesting is the development in energy-efficiency law where competitors started litigation, as discussed by Thomas Schomerus. 


\section{THE ROLE OF THE CJEU IN FURTHERING ENVIRONMENTAL PROTECTION}

\subsection{The Flow of Environmental Case Law}

Several chapters stand out for their discussion of a large number of court decisions, such as the chapters on more stringent national measures, the internal market, direct effect, environmental impact assessment, nature conservation, air quality, and waste. ${ }^{102}$ Particularly the chapters discussing substantive elements of EU environmental law show how important the case law is for interpreting EU environmental legislation. But what if a student asks what the ten most important cases are to concentrate on when studying EU environmental law? ${ }^{103}$ Given the vast amount of case law in this field, and the fact that it is hard to state which environmental value deserves a higher ranking than others, we believe it is impossible to provide an answer to this question on the basis of the chapters of this book. However, particularly where it comes to the concepts that have an impact on the whole field of EU environmental law (and beyond), such as the doctrine of direct effect, ${ }^{104}$ the inter-institutional relationships concerning the EU's external representation, ${ }^{105}$ and the interpretation of Article 263 TFEU related to standing, the Court's decisions have had a large impact. ${ }^{106}$

This role is not always stimulating environmental protection: the (in view of many infamous) Greenpeace case, ${ }^{107}$ in line with the Plaumann doctrine, ${ }^{108}$ shows a clear reluctance of the Court to enable access to the court for ENGOs. ${ }^{109}$ More than 50 years after Plaumann, the 2019 Carvalho case shows that the approach of the Court has not changed. ${ }^{110}$ Also the Bettati v Safety Hi-tech case $e^{111}$ from 1998 to which several authors refer, has confirmed that EU environmental legislation does not need to pursue the highest protection possible. Next to this, case law that allows for more opportunities for the EU legislator to pursue environmental protection may cause feelings of resistance and criticism to this EU influence, such as in the 2018 case of Poland $v$ the European Parliament and the Council, ${ }^{112}$

102 Discussed by Leonie Reins, Geert van Calster, Ludwig Krämer, Agustín García-Ureta, An Cliquet, Kendro Pedrosa and Bernard Vanheusden, and Chris Backes, respectively.

${ }_{103}$ See more generally on EU law: Mattias Derlén and Johan Lindlom, 'Goodbye van Gend and Loos, Hello Bosman? Using network analysis to measure the importance of individual judgments' (2014) 20 European Law Journal, 5, 667-87, 668.

104 As discussed by Ludwig Krämer.

105 As discussed by Antonio Cardesa-Salzmann and Elisa Morgera.

106 General doctrines of EU law (such as direct effect) have of course generally a large impact on the EU environmental law field.

107 Case C-321/95 P, Stichting Greenpeace Council (Greenpeace International) and Others v Commission ECLI:EU:C:1998:153, on appeal from an Order of the CFI in Case T-585/93, Stichting Greenpeace Council (Greenpeace International) and Others v Commission ECLI:EU:T:1995:147.

108 Case 25-62, Plaumann \& Co. v Commission ECLI:EU:C:1963:17.

109 Matthijs van Wolferen and Mariolina Eliantonio.

110 At least as confirmed by the General Court in Case T-330/18, Armando Carvalho and Others $v$ European Parliament and Council of the European Union ECLI:EU:T:2019:324, appeal is pending at the time of writing.

111 Case C-341/95, Bettati v Safety Hi-Tech ECLI:EU:C:1998:353.

112 Case C-5/16, Poland v European Parliament and Council ECLI:EU:C:2018:483 (discussed by Helle Tegner Anker and Stefan Weishaar). 
although it remains to be said that the political implications of the CJEU case law can be better examined in (or together with) other disciplines than law. Next to this, the direction of the case law is not always easy to understand. This can be illustrated with respect to Article 193 TFEU: the limits to the possibility for Member States to adopt more stringent environmental measures have not yet sufficiently crystallized, and only with courageous Member States taking such measures is it possible that clarifying case law can emerge. ${ }^{113}$

Instead of engaging into an identification and ranking of the most important court decisions in the field of EU environmental law (no matter how interesting this exercise may be), we sketch in this section trends and examples that illustrate how the CJEU has played a role in putting the objectives of EU environmental law to fruition. ${ }^{114}$

\subsection{The CJEU's Methods of Judicial Reasoning and the Casuistic Character of its Decisions}

One may wonder whether the CJEU's approach in environmental matters deserves a discussion on its own, and whether it can be distinguished from the approach adopted in other disciplines. General discussions about the adjudication by the Court are important, and sometimes one may see observations about the Court's approach in certain domains, such as with fundamental rights, where it is observed that the Court is 'self-referential', 'formulaic' and 'minimalist' in its reasoning. ${ }^{115}$ Also the question of whether the CJEU takes an activist or political role is an important one, but not easy to answer. ${ }^{116}$ This discussion needs to take place under the recognition that judicial authority is constrained by democracy and rule of law. ${ }^{117}$ In light of this, it would have become politically sensitive if the court had decided against the will of the institutions when assessing what the appropriate level of environmental protection is. Throughout this book, we have not seen the discussion of any example of such an approach. ${ }^{118}$

Another angle for discussing the method of judicial decision-making could try to assess the intensity with which the Court carries out its review. Generally, some chapters of this book call for intense adjudication. For example, in the light of the many implementation problems related to environmental impact assessment legislation, it is argued that ' $[\mathrm{C}]$

113 The case law regarding Article 193 TFEU is discussed by Leonie Reins.

114 Francis Jacobs already pointed at the difficulty to explain the role of the CJEU in the protection of the environment given the vast amount of court decisions. Francis Jacobs, 'The role of the European Court of Justice in the protection of the environment' (2006) 18 Journal of Environmental Law 2, 185-205.

115 Gráinne de Búrca, 'After the EU Charter of Fundamental Rights: The Court of Justice as a human rights indicator?' (2013) 20 Maastricht Journal of European and Comparative Law 2, $168-84,168$.

116 See for the methodological challenge for carrying out such analysis, Mark Dawson, 'How does the European Court of Justice reason? A review essay on the legal reasoning of the European Court of Justice' (2014) 20 European Law Journal 3, 423-35.

117 Dawson, ibid. (discussing the book of Gerard Conway), 425.

118 See with regard to the setting of the level of environmental protection in Member States the case law discussed by Geert van Calster in which the CJEU has expressly held that the setting of the level of protection is up to the Member States themselves, in the absence of Union harmonization. See also section 4.4 of this chapter. 
lose scrutiny of these matters is central to a successful application of EIA as a forecasting mechanism, but also to the achievement of a high level of environmental quality.' ${ }^{119}$ Such close scrutiny may be more easily applied by the Court, or be more acceptable in case of procedural requirements than in cases concerning substantive issues, such as is the case with principles. ${ }^{120}$

The immense complexity of EU environmental law, partly caused by the diverse character of the regulatory approaches, may be one of the important reasons for the casuistic approach that characterizes case law of the CJEU. ${ }^{121}$ However, this casuistic character can also be identified in relation to general concepts of EU law, such as in the case of EU competences and the choice of legal basis. ${ }^{122}$

Another element of the casuistic character of the case law is that the emergence of cases of course depends on whether legal claims are submitted. ${ }^{123}$ For the IED and the issue of public participation in environmental decision-making, few cases (in the form of preliminary references sent by national courts) have reached the CJEU, while in the case of other substantive legislation, such as nature conservation or the EU ETS, many cases have emerged. ${ }^{124}$ How can such differences be explained? Further research would be needed to understand why some environmental fields seem to be more prone to environmental litigation than others.

One of the methods the Court often uses is the teleological interpretation, meaning an interpretation that aims to strengthen the aim of the adopted provision. ${ }^{125}$ Poor reasoning by the Court however prevents us from assessing the method and correctness of the judicial interpretation. ${ }^{126}$ Ludwig Krämer has even identified 'a clear contradiction in the case law of the CJEU' in relation to the question of whether the courts have to set aside a national provision that contradicts EU law, when this provision does not have direct effect. All in all, however, his chapter shows that the CJEU in its decisions strengthens the possibility of individuals and ENGOs to enforce provisions of EU environmental legislation, which fits with the observation that the CJEU generally finds solutions that contribute to environmental protection. ${ }^{127}$

\footnotetext{
119 As stated by Agustín García-Ureta.
}

120 See the chapter from Gyula Bándi, who explains that the CJEU articulated the meaning of the precautionary principle, but still allows for a high level of discretion for the decision-makers in applying this principle.

${ }_{121}$ Ludwig Krämer observed in an earlier writing the 'pragmatic' approach of the CJEU with regard to principles: Ludwig Krämer, 'Environmental principles and the EU Court of Justice', in Ludwig Krämer and Emanuela Orlando (eds), Principles of Environmental Law (Edward Elgar 2018), 597.

${ }_{122}$ Antonio Cardesa-Salzmann and Elisa Morgera.

123 See the chapter by Thomas Schomerus, referring to a chart developed by the Sabin Centre for Climate Change Law and observing a striking difference in climate litigation between the US and the EU.

124 See the chapters from Lolke Braaksma and Hanna Tolsma, An Cliquet, and Stefan Weishaar, respectively.

125 For instance, Agustín García-Ureta discusses the teleological approach in EIA case law.

126 See Dawson, o.c. 430 ('the frequently poor reasons the Court provides to justify its decisions').

127 See also Krämer, o.c. 597, 'from an environmental point of view, the solutions found by the Court are generally acceptable.' This conclusion is shared by Leonie Reins in her chapter on more 


\subsection{The Need for Judicial Interpretation and the Role of the Court in Furthering EU Environmental Law}

In various subfields of EU environmental law, necessary clarifications of established legislative provisions have been provided by the CJEU, such as in the fields of nature conservation, access to information and waste. ${ }^{128}$ These clarifications are necessary because the legislation can leave certain key terms, such as the term 'significant' in the EIA Directive, undefined. On those occasions, the Court has intervened and has restricted the Member States' 'liberal' implementation of those terms, in order to enhance the level of environmental protection. ${ }^{129}$ The same conclusion can be reached with respect to the EU secondary measures in the field of nature conservation, with respect to which, for example, the Court ruled on the notion of 'deliberate' and gave this concept a strict interpretation. ${ }^{130}$

A very peculiar role for the Court and its hermeneutic function can be detected with respect to waste legislation. According to Article 6(4) of the Waste Framework Directive, 'Member States may decide on a case by case basis whether certain waste has ceased to be waste taking into account the applicable case law'. However, the question can be posed as to where this provision is more than a political statement, since it does not seem to provide further powers or impose further obligations on national authorities. ${ }^{131}$

In general, however, several authors do point out how an active and progressive case law by Court of Justice has provided significant input in the shaping of high environmental standards - this is the case, amongst others, for the field of GMOs, ${ }^{132}$ environmental impact assessment ${ }^{133}$ and of nature conservation ${ }^{134}$ - and in empowering citizens to challenge violations of EU environmental law. With respect to the latter point, specific mention should be made of a 2019 ruling, in which the Court of Justice confirmed the possibility for citizens to challenge the way a Member State measures and assesses air quality. ${ }^{135}$ Similarly, with respect to the legislation concerning access to environmental

stringent protective measures. Geert van Calster observes that many judgments have supported environmental goals over and above free trade, but that there is no evidence that this has been done more systematically than the case of other non-trade concerns.

128 See respectively the chapters by An Cliquet, Uzuazo Etemire, and Chris Backes.

129 Agustín García-Ureta.

130 Noted by An Cliquet.

131 Chris Backes, who makes a similar (although nuanced) statement also with respect to other provisions of the Waste Framework Directive.

132 Discussed by Giulia Claudia Leonelli, who refers to the Court's dynamic and evolutionary perspective on the legislative provisions concerning the mutagenesis exemption contained in the applicable legislation, thereby ensuring that, 'as long as scientific uncertainty persists on the public health and environmental risks that new mutagenesis techniques may pose, an environmental risk assessment is undertaken and post-marketing monitoring is in place'.

133 Discussed by Agustín García-Ureta, who discusses, for example, the Court's case law which has restricted the margin of manoeuvre of the Member States as to which project may be subjected to an environmental impact assessment.

134 Discussed by An Cliquet. For example, she discusses how the Court held that social or economic criteria must not play a role in the designation or non-designation of an area as protected under the applicable legislation.

135 This is discussed in the chapter by Kendro Pedrosa and Bernard Vanheusden. Case C-723/17, Craeynest ECLI:EU:C:2019:533. 
information, the CJEU held that the term 'emissions into the environment' could not be interpreted restrictively and should not be limited to information on 'actual emissions' into the environment, but should include information on 'foreseeable emissions'. ${ }^{136}$ Along the same lines, 'the court has again and again stressed that the term "waste" cannot be interpreted restrictively'. ${ }^{137}$

The CJEU has also played a decisive role in furthering the precautionary principle in EU environmental law. While this principle is codified in the environmental chapter of the TFEU, without a definition, the CJEU articulated the meaning of this principle in several cases, at first in cases outside the core environmental law field, namely food safety in relation to human health. ${ }^{138}$

Also, in the context of litigation related to the choice of the correct legal basis, the Court supported - or even broadened - the possibility to adopt decisions aiming to protect the environment. It did so by endorsing the use of Article 192(1) instead of 192(2) TFEU as a legal basis - and thereby circumventing the requirement of unanimity in the Council. It thereby held that the choice of legal basis needs to be based on an objective examination of the real content and character of the proposed legislation and its linkages to the aims pursued vis-à-vis a possible, more restrictive, effect-based approach. ${ }^{139}$ The same pro-active attitude can be detected with respect to the financial sanction under the infringement proceedings. ${ }^{140}$ This approach has also been reiterated with respect to the possibility to order interim measures, where, in a case against Poland brought to prevent destruction of an ancient forest, the Court introduced a financial penalty, by analogy with Article 260 TFEU, where this possibility does not explicitly exist in the Treaty. ${ }^{141}$

Similarly, in areas where the co-legislators have struggled to ensure an appropriate level of harmonization, such as in the case of the Environmental Liability Directive ${ }^{142}$ and the lack of support to harmonize overall inspection criteria, ${ }^{143}$ the CJEU has played a significant role in furthering the harmonization process by providing an interpretation of provisions which had been very differently implemented by the Member States, thereby reducing their margin of manoeuvre. ${ }^{144}$ Finally, in the area of nature conservation, the purposive role of the CJEU even manifested itself in an inter-institutional struggle, where

136 Chapter by Uzuazo Etemire.

137 For example, Joined cases C-418/97 and C-419/97, ARCO Chemie Nederland Ltd v Minister van Volkshuisvesting, Ruimtelijke Ordening en Milieubeheer and Vereniging Dorpsbelang Hees, Stichting Werkgroep Weurt+ and Vereniging Stedelijk Leefmilieu Nijmegen v Directeur van de dienst Milieu en Water van de provincie Gelderland ECLI:EU:C:2000:318, para. 40.

138 Chapter by Gyula Bándi.

139 Further on this point (particularly with regard to Case C-5/16, Poland v European Parliament and Council ECLI:EU:C:2018:483) the chapter by Helle Tegner Anker.

140 Chapter by Melanie Smith.

141 Case C-441-17 R, Commission v Poland ECLI:EU:C:2017:877, discussed by Melanie Smith.

142 The problems related to harmonization of environmental liability are discussed by Barbara Pozzo.

143 Discussed by Martin Hedemann-Robinson.

144 Agustín García-Ureta explains this phenomenon with regard to Environmental Impact Assessment legislation. Gyula Bándi discusses case law related to the Environmental Liability Directive. 
the strict approach taken by the Court was subsequently relaxed by the legislator, only to be tightened again by the Court's intervention. ${ }^{145}$

While this attitude may be duly appreciated as enhancing the effectiveness and development of EU environmental law (with respect to the Habitats Directive, it has for instance been stated that the case law represents an example of 'sensible environmentalism in the courtroom'146), legal scholarship may continue to discuss whether and to which extent the jurisprudence of the CJEU borders into 'judicial activism' ${ }^{147}$

\subsection{Balancing EU Environmental Interests with Other Interests}

While the CJEU in several cases has clearly contributed to furthering environmental protection, as discussed in the previous section, one of the peculiar, and perhaps the most difficult issue in environmental law, is the balancing of environmental interests with other social and economic concerns. This balancing exercise is captured in the concept of sustainable development, which is codified in an inconsistent way throughout the Treaties and the Charter, and, moreover, has not been defined. ${ }^{148}$ Article 11 TFEU - the external integration principle - does not state that a high level of environmental protection needs to be considered, although Article 37 of the Charter does. But even under the requirement to achieve a high level of environmental protection, the legislator is allowed to balance environmental protection with other interests - given the fact that, according to the CJEU, a high, but not the highest, level of environmental protection needs to be striven for. ${ }^{149}$ The few cases in which the CJEU has considered sustainable development show that this concept may only serve as a point of general reference, but does not have a direct impact on the outcome of a case. ${ }^{150}$ At the same time, given the fact that sustainable development has emerged from ecological concerns, one could still argue that environmental protection should be taken as a priority in cases of conflicts between different goals. ${ }^{151}$ However, in pushing this idea through, the CJEU could be overstepping its competence.

The principle of external integration also challenges the Union institutions to balance the environmental concerns with other interests. However, the incorporation of various integration requirements in the TFEU (Articles 8-13 TFEU) next to the already existing single environmental integration reference (now in Article 11 TFEU) entails the risk that the environmental interest is watered down. ${ }^{152}$

Also several treaty provisions require that EU institutions have a task to balance several interests: for example, Article 191 TFEU obliges EU environmental policy-makers to take into account 'the economic and social development of the Union as a whole and the

145 See the chapter by An Cliquet and the case law discussed therein.

146 Hendrik Schoukens and An Cliquet, 'Biodiversity offsetting and restoration under the European Union Habitats Directive: balancing between no net loss and deathbed conservation?' (2016) 21 Ecology and Society 4, 10; quoted by An Cliquet.

147 Mark Dawson, Bruno De Witte and Elise Muir, Judicial Activism at the European Court of Justice (Edward Elgar, 2013).

148 As discussed by Gyula Bándi (discussing the difficulty with enforcing this norm).

149 Case C-341/95, Bettati v Safety Hi-Tech ECLI:EU:C:1998:353.

$150 \quad$ As discussed by Gyula Bándi.

151 Gyula Bándi.

152 Gyula Bándi. 
balanced development of its regions'. Generally, the Court grants 'a broad discretion' to the legislature 'where its action involves political, economic and social choices and where it is called on to undertake complex assessments and evaluations'. ${ }^{153}$ However, sometimes specific secondary legislation regulating such other interests - such as Council Directive 2000/43/EC of 29 June 2000 implementing the principle of equal treatment between persons irrespective of racial or ethnic origin - can lead to the unlawfulness of a specific environmental measure: the energy efficiency chapter discusses a decision in which the Court found a national measure unlawful because of its discriminatory effect on the grounds of ethnic origin. ${ }^{154}$ This is one of the rare examples where the CJEU has contributed to the further development of what can be called 'environmental justice'. ${ }^{155}$

The balancing act implies that authorities necessarily need to have discretion, as is evident in many domains, such as the EIA Directive. ${ }^{156}$ Also the integrated emissions permit approach as regulated by the Industrial Emissions Directive, logically - because of the integration aim - entails a need to balance. Different from the principle of external integration, here an internal integration is required, meaning that the various emissions in several environmental media have to be considered with the aim to optimize a high level of protection of the environment as a whole. This balancing act includes some flexibility for authorities regarding the content of the permit. ${ }^{157}$ Here, active public participation is key to check the decision-making of permitting authorities, although the intensity of judicial review regarding the substantive balancing that an authority makes using the flexibility provided by the Industrial Emissions Directive remains a question to be further examined. In that context, it should be mentioned that the Court of Justice does not prescribe a specific intensity of review of discretionary choices of national authorities in environmental matters, but has stated, in the context of national litigation in the field of access to environmental information, that national courts should exercise a judicial control which is at least sufficient to apply effectively the relevant principles and rules of EU law. ${ }^{158}$

While some secondary environmental legislation tasks Member States with executing a balancing exercise, thereby providing large discretion in order to do so, ${ }^{159}$ other secondary

153 Case C-127/07, Société Arcelor Atlantique et Lorraine and Others v Premier ministre, Ministre de l'Écologie et du Développement durable, Ministre de l'Économie, des Finances et de l'Industrie ECLI:EU:C:2008:728, para 57, with reference to earlier case law.

154 Case C-83/14, CHEZ Razpredelenie Bulgaria AD v Komisia za zashtita ot diskriminatsia ECLI:EU:C:2015:480, discussed by Thomas Schomerus.

155 See for a discussion of the human rights perspective section 4.5.

156 Chapter by Agustín García-Ureta.

157 As discussed by Gyula Bándi, and Lolke Braaksma and Hanna Tolsma.

158 Case C-71/14, East Sussex County Council v Information Commissioner, Property Search Group and Local Government Association EU:C:2015:656, para 58. See further on this point and the case law, M. Eliantonio, 'The impact of EU law on access to scientific knowledge and the standard of review in national environmental litigation: a story of moving targets and vague guidance'(2018) European Energy and Environmental Law Review 115.

159 The Water Framework Directive provides an interesting example in this respect, since it has codified that sustainable development can serve as a justification for not reaching the highest water quality standard. See the chapter from Gyula Bándi and more particularly Case C-43/10, Nomarchiaki Aftodioikisi Aitoloakarnanias and others v Ipourgos Perivallontos, Khorotaxias kai Dimosion Ergon and others ECLI:EU:C:2012:560, para.139. 
legislation sets a clear environmental target - such as the cap for the EU Emissions Trading System - which implies that no balancing exercise has to be carried out in the implementation process. At the same time, it can be questioned whether the adopted maximum limit for the emissions of greenhouse gases until the year 2030 is sufficiently ambitious given the interests of future generations. ${ }^{160}$ However, while it is commonly understood that sustainable development includes the need to take the interests of future generations into account, this specific element is not explicitly mentioned in the treaties. ${ }^{161}$

Furthermore, the balancing between economic interests and environmental protection is evident in the field of internal market law. Actually, it was already 'the Founding Fathers' intention to make room for non-trade concerns trumping free trade'. ${ }^{162}$ Former Advocate General (AG) Jacobs observed that the court is prepared to go far in accepting environmentally-friendly measures - also when this impacts on trade, although, in his opinion, consistent reasoning lacks. ${ }^{163}$ The Court has engaged in judicial law-making by inventing the mandatory requirements on the basis of which national restrictions to intra-EU free movements of goods may be justified, of which environmental protection is one. ${ }^{164}$ However, uncertainties for Member States in adopting environmental measures that impact on the free movement of goods and services still remain, which in turn may have a freezing effect on national environmental measures. While the critique on the Court's case law (being 'unconvincing') is explicitly made clear by AG Bot, the result thus far is that specific national measures particularly in the field of renewable energy law seem to profit from a lenient approach on the part of the CJEU. ${ }^{165}$

All in all, the need for balancing different interests is entrenched in the treaties and has to be carried out first and foremost by the EU legislator. The transparency of the decision-making, including the disclosure of (draft) impact assessment reports, is guaranteed to a large extent by the access to information provision. ${ }^{166}$ This is perhaps the most important role the CJEU can fulfil: to ensure the respect of a proper procedure, including its transparency, in the decision-making in which conflicting interests have to be balanced.

\subsection{Human Rights Approaches Emerging in Environmental Law}

Given the thus far limited case law in this area, we have not invited a specific chapter on the meaning of the Charter of Fundamental Rights of the European Union from an environmental perspective. One can even observe that, so far, not much attention has been paid by scholarship on the potential for human rights to the furthering of the objectives

160 See about the package of laws the chapters from Estelle Brosset and Sandrine MaljeanDubois, Seita Romppanen, and Stefan Weishaar.

161 Only the preamble of the Charter refers in a general sense to the yet unborn: 'Enjoyment of these rights entails responsibilities and duties with regard to other persons, to the human community and to future generations.'

162 As stated by Geert van Calster in his chapter.

163 Jacobs o.c. 189 and 194.

164 Geert van Calster.

165 See for this critique, Geert van Calster.

166 Uzuazo Etemire. 
of EU environmental law. ${ }^{167}$ The Charter of Fundamental Rights of the European Union is rather brief on this topic, and, in its Article 37, refers to the principle of high level of protection and of integration, together with that of sustainable development, which are all mentioned in other primary law provisions. ${ }^{168}$ From this perspective, it can be questioned to what extent Article 37 provides in itself added value for the protection of the environment.

Nonetheless there are cases in which the CJEU refers to the Charter, although not necessarily to Article 37 thereof. Indeed, for example, the CJEU relied on Article 42 of the Charter, together with the relevant EU environmental legislation, in deciding that the refusal by the Commission to grant a request for access to certain environmental information was unlawful. ${ }^{169}$ Article 37, on the other hand, seems not to have been used often by the Court, ${ }^{170}$ and the Court has also clarified that this provision is not in itself able to grant rights to individuals. ${ }^{171}$

At the same time, especially with respect to water policy, it seems that the strengthening of the participatory approach, in combination with an increased focus on human rights, will bring new elements into the discussion of future European water governance. ${ }^{172}$ The European institutions also have embraced a human right perspective in this context, and, for example, the Commission has stated that access to safe drinking water and sanitation is a component of EU fundamental rights and that all states 'bear human rights obligations regarding access to safe drinking [water]'173 in respect of international law. ${ }^{174}$

Finally, although at a very embryonic stage of development, mention should be made of the applicability of the Charter in the context of more stringent national environmental measures adopted under Article 193 TFEU. At the moment, this applicability has only been explicitly confirmed by AG Kokott's opinion in the Tallinna Vesi case. ${ }^{175}$ It is to be hoped that future case law will clarify this point. If the Court confirms this approach, it

167 See however Elisa Morgera and Gracia Marín Durán, 'Environmental protection' in Steve Peers, Tamara Hervey, Jeff Kenner, The EU Charter of Fundamental Rights: A Commentary (Hart, 2010), 983-1004.

${ }_{168}$ This is mentioned by Gyula Bándi in his chapter on principles of EU environmental law, who also argued that the inconsistencies in terminology between Article 47 of the Charter and Article 11 of the TFEU ought to be resolved.

169 Case C-57/16, Client Earth v European Commission ECLI:EU:C:2018:660. This is discussed further in the chapter by Uzuazo Etemire.

170 A search in the Curia search engine yielded, as of 18 October 2019, only 12 hits. Of those, 1 case was declared manifestly inadmissible and not discussed in substance.

171 Case T-600/15, Pesticide Action Network Europe (PAN Europe) and others v Commission ECLI:EU:T:2016:601 where it was held (para. 47) that:

it suffices to observe that that article only contains a principle providing for a general obligation on the European Union in respect of the objectives to be pursued in the framework of its policies, and not a right to bring actions in environmental matters before the Courts of the European Union.

172 Observed by Nathalie Hervé-Fournerau.

173 SWD (2017) 449, Impact assessment related to the proposal for DWD.

174 This is discussed further in the chapter by Nathalie Hervé-Fournerau.

175 Case C-60/18, Tallinna Vesi ECLI:EU:C:2018:969, discussed by Leonie Reins. 
might not be unthinkable that fundamental rights such as that to property or to conduct a business will provide additional restrictions to further going national environmental measures.

Another side of the same human rights coin is the contribution of the ECHR to the protection of environmental law. In this context, the case law of the European Court of Human Rights, which has interpreted the ECHR, and specifically Article 2(1) on the right to life and Article 8 on the right to private and family life, has expanded the possibilities to obtain access to information about significant environmental risks to humans. ${ }^{176}$ Finally, a noteworthy case for its interaction between EU environmental law and the ECHR, is the case Cordella et al. $v$ Italy, ${ }^{177}$ in which Italy was held in violation of various provisions of the ECHR as a consequence of its inertia in complying with an earlier ruling of the CJEU declaring the country in breach of the Industrial Emissions Directive. ${ }^{178}$

While the empirical material collected is not sufficient to conclude on potential for human rights law to further the objectives of EU environmental law, it is safe to state that human rights approaches are on the rise in the context of environmental law. ${ }^{179}$

\section{FORWARD LOOK ON EU ENVIRONMENTAL LAW}

Given its width and complexity, a book of 30 chapters is too limited to provide a full discussion of each and every aspect of EU environmental law. This book's aim is not to be comprehensive but selective and, evidently, while important topics have been covered, others - such as aviation and shipping emissions, ${ }^{180}$ noise regulation or the role of the European Ombudsman and European Citizen's Initiatives in environmental matters have been left out. ${ }^{181} \mathrm{We}$ also acknowledge that, with regard to the topics covered, still much remains to be done also to deepen the understanding of EU environmental law, such as why certain regulatory provisions might be more prone to litigation compared

176 See case Oneryildiz v Turkey, application no. $48939 / 99$ (18 June 2002). Guerra v Italy, case no. 116/1996/735/932 (19 February 1998). McGinley and Egan v United Kingdom, case no. 10/1997/794/995-996 (9 June 1998). This case law is discussed in the chapter by Uzuazo Etemire.

177 Joint applications no. 54414/13 and n. 54264/15 (24 January 2019).

178 See shortly the chapter by Lolke Braaksma and Hanna Tolsma.

179 See in this respect the Dutch Urgenda case in which the ECHR served as an important argument to award the claim to order the State of the Netherlands to increase its emission reduction ambition to $25 \%$ in 2020: Urgenda $v$ The Netherlands (The Hague District Court, 24 June 2015) ECLI:NL:RBDHA:2015:7196. The ruling has been confirmed on appeal in The Hague Court of Appeal, 9 October 2018, and thereafter appealed with the Supreme Court of The Netherlands (pending at the time of writing). Next to this, in case T 330/18 individuals (and one NGO) argued that EU climate legislation infringes their fundamental rights as enshrined in the Charter of Fundamental Rights of the European Union because of a too low emission reduction ambition. The General Court found the action for annulment and damages inadmissible. Case T-330/18, Armando Carvalho and Others v European Parliament and Council of the European Union ECLI:EU:T:2019:324. The appeal is pending at the time of writing under number C-565/19 P.

180 The EU ETS chapter from Stefan Weishaar touches upon the regulation of greenhouse gas emissions from aviation.

181 Although specifically in the field of water law, Nathalie Hervé-Fournerau has discussed a specific European Citizen Initiative in her chapter. 
to others, or what kind of EU regulatory measures have been poorly applied at Member States level compared to others, and why. The application of EU environmental law by national authorities is still, largely, a black box and it is to be hoped that, in the future, more comparative law research will be carried out regarding the on the ground implementation of EU environmental law and the effectiveness of the plethora of regulatory approaches taken to ensure a high level of environmental protection. ${ }^{182}$ This, in turn, might be used to evaluate EU legislation and possibly generate more evidence-based legislation in the future.

Furthermore, we expect that important new developments will occur through technological innovation (such as satellite monitoring, but also the much needed innovations to move towards a carbon-neutral society) and innovative new research tools (such as big data analysis which can provide new insights into case law, its relationship and trends). At the same time, it will be important to monitor these technological developments to ensure that they do not, paradoxically, leave the environment worse off and ENGOs with reduced tools to monitor the effective application of EU environmental law. In this context, one might consider how algorithmic decision-making could be used to carry out an environmental impact assessment and the correlated challenges to control the machine-generated outcome through the orthodox judicial review tools and principles.

The need for action - to combat, among others, climate change, biodiversity loss, and plastic soup - has in the course of 2018 and 2019 not only become clear given the disclosure to governments and to the public at large of scientific information such as that provided by the European Environmental Agency, ${ }^{183}$ but is also often stressed by many of the young generation. Illustrative of the recognition of the need to take more ambitious action are also large donations given to the ENGO community in order to pursue legal action. ${ }^{184} \mathrm{~A}$ crucial point in this respect is how civil society can hold the EU decision-makers, and the national authorities, legally to account in order to apply, and also, improve, the EU environmental acquis. The large financial donation to ENGOs is one step forward to ensure that EU environmental law will have a larger impact in practice, although with increasing litigation, the role of the judiciary will need to be further scrutinized by legal scholarship, too.

182 Next to the (idle?) hope that, as argued in this book, the EU will succeed in establishing more adequate inspection and enforcement powers at EU level.

183 See about the task of the EEA to provide information as a basis for policy-making, the chapter by Annalisa Volpato and Ellen Vos.

184 As can be illustrated by the financial donation to Client Earth of more than 18 million euro after the sale of many of his guitars by David Gilmour in 2019, see: https://guinnessworl drecords.com/news/2019/6/david-gilmour-sells-his-guitars-to-raise-21-million-for-climate-changecharity-580749. 
Marjan Peeters and Mariolina Eliantonio - 9781788970679 Downloaded from PubFactory at $04 / 26 / 2023$ 11:24:43AM via free access 